\title{
BRITSE KOLONIALE BELEID IN AFRIKA.
}

Oor die geheel kan gesê word dat die Verenigde Koninkryk steeds meer op die Amerika's en sy Statebond eerder as op Europa steun vir sy voortbestaan as groot moondheid van die tweede rang.

In hierdie verband is dit die bedoeling en blykbaar die bestemming dat Afrika steeds 'n belangriker rol sal speel, eenvoudig omdat dit die enigste oorblywende eksploïtasie-gebied vir Europa en meer bepaald vir Brittanje is, en ook omdat die dominiums buite Afrika blykbaar steeds nouer sal skakel met die Verenigde State aan die een kant en met Rusland en China aan die ander kant.

Terwyl voorheen die Britse beleid in Afrika, veral ook deur onsself, verdoem is as imperialisties, word dit nou gekenmerk deur 'n liberalisme wat byna dié van die V.V.O. ewenaar en wat vir die blanke gemeenskappe in Suidelike Afrika onheilspellende konsekwensies inhou.

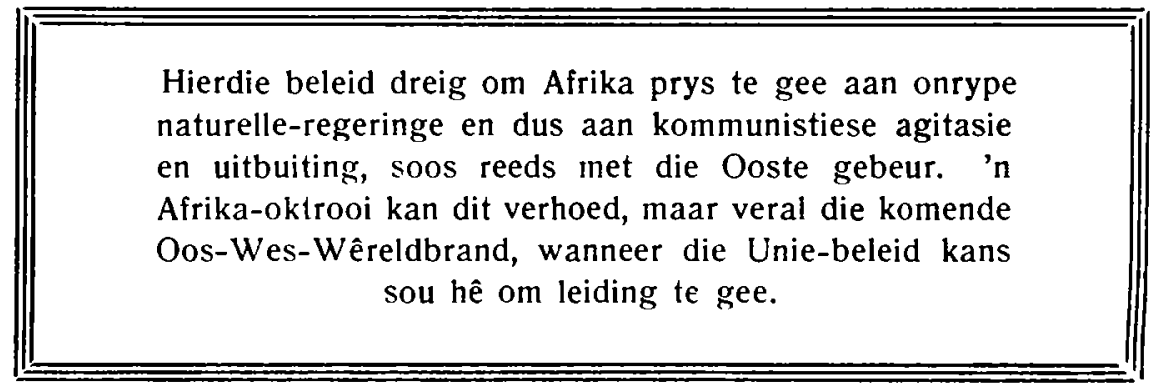

Ons eie houding is natuurlik nòg imperialisties nòg liberalisties, maar is gebaseer op erkenning van die feit dat, aan die eenkant, die ontwikkeling van Afrika vir onafsienbare tyd nog blanke leierskap vereis, en op die beginsel dat, aan die anderkant, die inheemse bevolkinge van Afrika geleidelik opgevoer moet word tot groter selfstandigheid namate hulle daartoe opgroei.

Brittanje daarenteen het, veral sedert die Tweede Wêreld-oorlog, onder die druk van allerlei omstandighede, hom hoofsaaklik daarop toegelê om aan die eenkant Duitse en Italiaanse imperialisme uit Afrika te weer, en aan die anderkant, ná die prysgawe van die Indiës, ook in Afrika 
so ver moontlik en so vinnig moontlik die inheemse bevolkinge sogenaamd selfstandig te maak.

Laat ons in hierdic verband, tussen hakies, as 'n saak van beginsel, net daarop wys dat vreemde oorheersing nie in alle omstandighede 'n blote - euwel is nie, en dat die vrymaking van nasies nie in alle omstandighede 'n seen is nie: dit hang alles af van die relatiewe grade van ontwikkeling. $\mathrm{Ja}$, hoewel ons die skeidslyne tussen nasies en rasse erken, kan soms selis ook vermenging gewens wees Dit alles natuurlik in die lig van ons Calvinisties-Skriftuurlike beginsels gesien, wat sowel nasionale selfhandhawing as nasionale selfoplossing in omstandighede verorden, en sowel leierskap as vryheid en selfstandigheid, na gelang van omstandighede.

Hoe dit sy, in Afrika het Brittanje nou as beleid aanvaar die spoedigs moontlike vrymaking van die verskillende inheemse gemeenskappe en die invoering van 'n aangepaste demokratiese bestuurstelsel wat ten slotte die oppermag moet plaas in die hande van die naturellegemeenskappe, of liewer van hulle agitators en demagoge van kommunistiese of soortgelyke mentaliteit.

Hierdic beleid is in Afika, by alle onderlinge verskille van gebied tot gebied, tipies Brits, aangesien die ander Europese koloniserende moondhede in Afrika almal die beheer in die moederland konsentreer, en SuidAfrika reeds 'n eie koers ingeslaan het. Natuurlik hoop Brittanje om deur sy beleid nie alleen teen minder eie koste Afrika te laat ontwikkel nie, maar ook om verder besondere welwillendheid en voorregte te geniet van die kant van die vrygemaakte gemeenskappe.

Ter uitvoering van hierdie beleid is reeds die volgende belangrikste stappe gedoen.

In die eerste plek is, met die feitlike uitskakeling van Italië, die hele Noord-Oostelike kwart van Afrika prysgegee, gedeeltelik aan Egipte en origens aan verwaarlosing, hoew'el daar nog gepoog word om 'n mate van beheer te behou oor Suez en Soedan.

In die tweede plek is die streek ten Noorde van die Golf van Guinea of Brits Wes-Afrika "geseën" met 'n meerdere of mindere mate van selfbestuur onder die geestelike leierskap van Nkrumah met diersimbole as onderskeidingstekens by verkiesinge en 'n groot verskeidenheid van verkiesingsmetodes. 
In die derde plek is die Sentraal-Afrikaanse Federasis gestig met besondere beskerming vir naturelle-belange en is ook 'n begin gemaak met 'n Oos-Afrikaanse Federasie.

En ten vierde word nog steeds geweier om die Suidelike Protektorate aan die Unie toe te vertrou sonder "raadpleging” met die betrokke inboorlinge.

Van hierdie liberalistiese en verkeerdelik as Christelik aangeprese maatreëls het Brittanje nog nie juis veel plesier belewe nie, al probeer hy ook ernstig om oral in Afrika so gou moontlik oor te gaan van ,trusteeship" na „partnership”, op die prinsipiële grondslag van verwydering van alle diskriminasie vanweë ras, kleur of godsdiens, en al het hy ook 'n kapitaal van byna $£ 300,000,000$ ge-oormerk vir koloniale ontwikkeling op ekonomiese gebied.

Want ten eerste is in die algemeen die aandrang tot groter magte vir die naturelle-bevolkinge sedert die oorlogseinde oral so sterk en die Britse regemoetkomendheid so groot, dat die ontwikkelinge in die rigting van volledige dominium-status so vinnig plaasvind, dat dit moeilik is om daarmee tred te hou behalwe met behulp van 'n omvattende stelsel van koerant-uitknipsels, laat staan dan om enige bepaalde konsessie behoorlik uit te toets.

Ten tweede is daar in elk van die bogenoemde gebiede aanhoudend ernstige en selfs bloedige agitasies om nog groter konsessies. Ons noam bv. agtereenvolgens die voortdurende struweling tussen Egipte en Engeland, die aanhoudende opstootjies in Brits-Wes-Afrika, die Mau-Mauburgeroorlog en Kabaka-moeilikheid in Oos-Afrika, die stakings in Sentraal-Afrika en die rituele moorde ens. in die Suidelike Protektorate-dit alles nog afgesien van die onrus van die betrokke blanke gemeenskappe, wat hulself begryplikerwys verwaarloos voel.

Tog word nog steeds oral vinnig voortgegaan met die verdere verstewiging van koloniale selfstandigheid en die vermeerdering van naturelle-verteenwoordiging in koloniale regeringe, selfs in die Suidelike dele van Afrika, waar die plaaslike blanke gemeenskappe wel die eerste ontwikkeling verwelkom, maar die tweede op minder of meer openlike wyse weerstaan, gepaard met 'n suidwaarts steeds aangroeiende mate van voortdurende rasse-diskriminasie. 
Socs bekend is die beleid van die Unie op laasgenoemde punt ook in ontwikkeling begrepe en wel in teenoorgestelde rigting as die algemeenBritse, nl. tot vermindering van naturelle-deelname in die bestuur van sake waarby ook blankes betrokke is, gepaard met 'n geleidelike ontwikkeling van betreklik selfstandige afsonderlike naturelle-gemeenskappe. Vandaar die botsing tussen die Unie-beleid en die Britse, en weer nog die V.V.O.-beleid, ten opsigte van Afrika.

In hierdie opsig staan die Unie-regering nog blykbaar alleen, maar dat sy houding wel gewig in die skaal moet gooi, word bewys nie net deur die vyandigheid van Nehroe en Nkruma nie, maar ook deur die onweerspreeklike syfers van die Unie se bevolking en produksie. Van alle gebiede in Afrika suid van die Sahara het die Unie naamlik nie alleen by ver die grootste blanke bevolking nie, maar ook die grootste naturellebevolking afgesien van Nigerıë en die Kongo, asook by ver die grootste nasionale inkomste, hoewel hoegenaand nie die grootste oppervlakte nie.

Tog is dit nodig om daarop te wys dat die Britse koloniale beleid, afgesien van die bogenoemde algemene tendens, in 'n groot verskeidenheid van konstitusionele vorme beliggaam is en dat vir die eintlike naturellegebiede die konflik met die Uniale beleid nie so onoorkoomlik is nie, behalwe dat die Unie waarskynlik al die Britse gebiede oortref in die grootte van uitgawes vir naturelle-ontwikkeling en in hierdie opsig meer ooreenkoms vertoon met die Belgiese Kongo, afgesien miskien van die Soedan, waar Brittanje met Egipte moet konkurreer.

Om hierdie rede o.a. is dit nie heeltemal ondenkbaar nie dat die verskillende koloniserende moondhede in Afrika mettertyd ' $n$ gemeenskaplike Afrika-Oktrooi mag ontwikkel, soos deur dr. Malan en ook reeds deur genl. Smuts voorgestel. Hierby sal Italië as aangewese kolonisator van Noord-Afrika moeilik gemis kan word, asook grootskaalse immigrasie in Duitsland en Nederland, verbonde met die finansiële rugsteun van die V.S.A.

Of uit so 'n Afrika-Oktrooi blywende en groter onderlinge politicke verbindinge sal voortvloei, moet vireers twyfelagtig bly, maar die ondervinding in Noord-Afrika skyn daarop te wys dat konfederale en selfs federale verbindings op betreklike groot skaal vir die toekoms nie heeltemal uitgesluit mag wees nie. 
En ingeval 'n wèreldbotsing sou ontbrand tussen die Ooste en Weste, met Afrika aan die kant van die Weste, sal sekerlik groter interne verbindinge verwag kan word, en daarby sal die Unie 'n groot rol kan speel deurdat sowel die plaaslike blanke gemeenskappe as die Westerse moondhede dan die lewensbelangrikheid sal moet erken van die fundamentele beleidsrigtinge van die Unie ten opsigte van rassekwessies, $n l$. ten eerste die beginsel van blanke leierskap nie net in feite nie, maar ook regtens; ten tweede die geleidelike ontwikkeling van naturelle-selfbestuur in afsonderlike naturelle-gebiede, en selfs in sekere gevalle in betreklik selfstandige naturelle-state, en ten derde die uitskakeling van Oosterse infiltrasie hetsy van Indie of van die Kommunisme.

Afgesien van hierdie vooruitsig egter is daar met die bestaande beleidsrigtinge neel goed kans dat die Britse Afrika-beleid deur die toelating van naturelle-dominiums tot die Statebond, en andersins, so mag bots met die Unie-beleid, dat die Unie hom verplig sal sien om die Statebond te verlaat, wat veral vir laasgenoemde 'n onoorkoomlike ramp sal wees. 